\title{
VALUE CHAIN MANAGEMENT AND INDUSTRIALIZATION IN AFRICA
}

\author{
Chimeziem C. Gabriela Udeze \\ Alex-Ekwueme Federal University, Ndufu Alike Ikwo \\ Joy N. Ugwu \\ Alex-Ekwueme Federal University, Ndufu Alike Ikwo
}

\begin{abstract}
:
The overwhelming competitive strength of developed and industrialized countries across the globe has constantly challenged the up-and-coming industries in African nations in a cold and stiff competition. This has left these industries perpetually on their marks and unable to take off so as to compete favourably with their competitors in the global market place. The question of how industries in Africa can improve their competitiveness and hence industrialize the continent has been widely discussed by scholars in the recent past and yet this issue has not been adequately addressed. This paper on value chain management and industrialization in Africa is a qualitative study that addresses the issue of African industrialization with special reference to value chain management. Specifically, this paper reviews how industries in Africa can thrive amidst stiff global competition and the role of value chain management in industrializing the African continent. Through deductive reasoning, the study reviews the role of value chain management in the industrialization of Africa. In conclusion, this paper shed more light on how industries in Africa can leave their marks, take off and compete favourably amidst stiff competition with value chain management pointing out that one of the ways to make African industrialization a reality is to manage the industrial value chain effectively. This study recommends that government and private organizations should help by investing in research and development to help shed more light on innovative ways to improve on value chain management.
\end{abstract}

Keywords: African industrialization, Value chain management, Competitiveness, Effectiveness

\section{Introduction:}

Political and economic independence make up what it takes for a country's national independence to be complete, meaningful and real. After achieving political independence, a majority of the African nations have consistently made frantic efforts to earn their economic independence which has remained a challenge till date (Ofor, 2017).

The rate of economic crisis and recession in African countries underscores their need for economic development which depends chiefly on industrialization. The total reliance of Nigeria on international products shows that, like other African countries, it lacks impulsion and autonomy in industrial development. African nations have been in the race for industrialization since achieving political independence, making so many efforts and yet showing few signs of mechanization, mass production, social change, automation, industrial development, and economic growth.

The central and established emphasis of economic activities in Nigeria since the 1960s and 1970s has been on the enlarged manufactured as well as export of agricultural/ primary commodities like oil palm, cotton, groundnuts, cocoa and rubber; and subsequently from the 1970s crude oil came up. The dependence of the raw material exports on external demand does 
not encourage the sovereignty and sustenance of economic activity resulting in the situation that the economy of Nigerian lacks the inner capacity to produce massively. It is a large economy which is dependent and unviable (Iweriebor, 2017).

Again, the indigenous African organizations find it difficult to break even and grow; they continually lack the economic capacity to stand and compete favourably with their much experienced, competitive and economically more stable global competitors. The value chains in these organisations are encumbered with so much cost that a good number of manufacturing organisations constantly fold up soon after their inception (due to poor performance attributed to high production costs, defective products, non-value adding activities, to mention but a few), some of them (still on the race) just manage to recoup their production costs staggering far behind a few others who are panting their way to success with great difficulty. (Udeze, 2013).

These African industries end up having no ability to stand and compete favourably with their competitors, globally and that has made them consistently unable to grow and increase in number so as to industrialize the continent.

Organisations can be seen as systems which comprise subsystems, each with its own production process (input, conversion process and output). The inputs, conversion processes, and outputs (production process of every organisation) involve the acquisition and utilisation of organisational resources: human capital and all non-human resources in the workplace. How these organisational resources are manipulated make up the value chain activities of the organisation, hence how the value chain activities are carried out determines costs and affects profits Microlinks (2009)

Due to the stiff global competitiveness and the uncertainty clouding the global business environment, African indigenous industries find it extremely difficult to compete favourably with their global counterparts; this has posed a great challenge to the industrialization of the continent. The alarming rate of inefficiency (in a global comparison) attributed to high production costs, defective products, non-value adding activities, poor product quality, archaic business procedures, to mention but a few, has marred the chances for businesses in the continent to compete successfully across the globe. It is becoming almost impossible for these indigenous organizations to adequately secure their positions in the marketplace; the incessant exit of African industries from the global market is therefore a big challenge to industrialization of the continent.

Unless businesses in the continent come up with strategies that will sustainably improve efficiency as well as self-propulsion and autonomy in industrial development, they will continue perpetually in their struggle to create and sustain global superior performance. This study therefore examines the circumstances of African industrialization and evaluates the benefits of organizations' value chain management, bringing to light how the effective management of value chain can affect industrialization in the continent.

The paper explores the principles of value chain management as they apply to organizations' production processes; how an organization would ensure a successful value chain management and also how proper management of the value chain system can impact on the efficiency of organizations. Nigeria became a focus of this study, as one among the up and coming countries in Africa, hence a good representation of the African continent. 


\section{The Literature Review:}

The literature for this paper was reviewed under the following: conceptual framework and empirical review.

\section{2a. Conceptual Review:}

The paper was organized along the concepts that make up the value chain Management and African industrialization, which includes: Value Chain, Value Chain Management, African Industrialisation and the effects of Value Chain Management on African Industrialisation.

\section{i. Value Chain:}

Organizations exist in all industries; for an organization existing in an industry to be able to complete the entire process involved in the production of its products for the market, the organization has to perform a chain of activities. This chain of activities represents the organisation's value chain. Hence, an organisation's value chain may be defined thus:

An organisation's value chain may include a pool of activities expected of organizations existing in a specific industry, in order to make available valuable products for the market. Products go through a chain of activities before they are presented to the market, additional value is usually gained in each activity. The chain of activities, gives the products more added value than the sum of added values of all activities (Porter, 1985).

This set of value adding activities that characterize an organization's value chain can, according to Porter (1985), be grouped into:

Physical value chain: This category of value chain, otherwise known as the traditional value chain, comprises all physical activities that are carried out in order to add value to and produce products for the market, i.e. physical value-chain enhancement process. The physical representation of all the activities focus on the physical value chain enhancement process, from the onset of the production process (raw material acquisition) up to product delivery (supply chain), can also be called the industrial value chain.

The dawn of computer-based technology gave way for a new market space, hence the next value chain:

Virtual value chain: This value chain consists of all activities performed in the on- line market space, here all the physical value-chain enhancement processes are practiced in the virtual value chain to improve the entire value chain process.

Global Value Chain (GVC): Global Value Chain represents value chains across borders or region in a bid to improve efficiency as well as optimize profit. International businesses create global value chains as they locate value chain activities in different countries across the globe; activities such as market research and development, product design, assembly, production of some parts or all of a product, advertising, marketing, product branding, offshoring, to mention but a few.

\section{ii. Value Chain Management:}

Value chain management (VCM) is the integration of all value chain activities in such a way that it not only results in an efficient production process but also creates a better product, one that gives value and satisfaction to the customers. 
It has been considered as a strategic business analytical tool used for the collaboration of value chain components and resources, which emphasizes the reduction of resources and assessment of value at every level of the chain, which results in the optimum process integration, decreased inventories, better products and enhanced customer satisfaction.

VCM was recommended by Michael Porter as a business management strategy as well as strategic planning tool for sustaining organisational performance by adding value to organisations' products and getting customer satisfaction (Ghemawat, 2002).

VCM extends from organizations to distribution and supply networks; it requires an integrated chain strategy, planning and scheduling, efficient supply chain, full and interdependent chain resource management and optimization and the integrated customer insight data and information.

Successful Value Chain Management requires that an organization should work hard to add value and effectively carry out the following:

Research and Development: This involves market analysis evaluating the trends in customer expectations in terms of quality, price and timing in order to meet these expectations. For that to be achieved, the suppliers and all along the chain will have to work together.

Product Design: New ideas that seem to meet customer demands should be designed in such a way that they meet the expectations of customers; also, if there is a need to modify an existing product as a result of research, it should be properly done at all the stages to add value.

Production Process: An efficient value chain entails that the production process should be as efficient as possible, the cost of production, the quality of product as well as value of products are significantly affected by the procedure and place of production. For international businesses the global value chain is significant to adding value to the process of production.

Marketing and Sales: for a product to turn out successfully, it must be marketable. The organization should not exhaust itself to market their products as it must offer value in every aspect. Successful products must satisfy their customers.

Distribution Management: The management of the distribution channel is quite important as the process determines the time, the state and the price at which the customers get the product. The warehousing process and the distribution links are critical factors as a product may leave the organization in good quality only to get to the customer in a horrible state, thus failing to meet customer expectations. The Distribution (logistics management) is therefore an important connection in the value chain. The entire activities here: transportation, product handling, packaging, communications and information have to be appropriately managed for the product to get to the customers meeting their expectations.

Customer Service: Most organizations neglect the importance of this value chain activity; it is not enough that customers get the products; they should be educated about the usefulness and operations of the product in order to get adequate value from using the product. Some people outside an organization come in between the customer and producer/organization to fill in that gap and thus add more value through the additional information they make available to the customer and hence get value from that. Organizations should train employees and charge them with the duty of filling the gap of customers' ignorance about products and usage of the 
products. Customer service, or what is called after sales service, is the last and most fragile link in the supply chain used by management to assess customers' opinion of their product.

\section{iii. Industrialisation in Africa:}

Industrialization requires the concentration of industries in a location, the actuality of industries is characterized by mechanization of the production process and mass production. That expresses social changes in the country as well as economic growth. As a way to economic independence, African nations have been struggling seriously to attain industrial development; nevertheless, industrialisation in Nigeria and other African countries has been constrained by some factors such as:

The belief that economic development can only come through foreign investments because African countries majorly produce raw materials and the neglect of local manufacturers; This notion is wrong although it seems true especially the fact that African countries consume much industrial products yet are barely able to export raw material (Ofor, 2017).

Also, the inability of the government to support entrepreneurs which gave rise to the prevailing industrial and technological backwardness because of lack of business research; this made it almost impossible for businesses to favourably compete with their counterparts in the developed countries.

Another constraint includes inadequate finance /capital, lack of technological know- how, mutual distrust that inhibits the entrepreneurs from pulling their resources together to form large and more profitable businesses, however, it is quite obvious that indigenous private business sector alone cannot industrialize Nigeria due to many reasons such as high cost of production that may have resulted from the constant use of generating sets as a result of the grossly inadequate and epileptic power supply from the national grid (Ofor, 2017).

The inefficiencies resulting from the chain of activities in the value system of industries, consistently left a majority of African industries without competitiveness and hence unable to grow and add to their country's gross domestic product.

\section{iv. Effects of value chain management on African Industrialisation:}

Industrialization means the conversion, on a large scale, of raw materials to finished products ready for public consumption or for further use in industry. It involves not only the processing of raw materials into finished products but also the preservation, packaging and storage of the finished products. Industrialization makes sure that the finished products are of an acceptable quality to the consumers. Basically, industrial raw materials are agricultural produce or mined ore and the interaction of energy and matter from which industrial products is derived is thus, mechanization and the provision of abundant and cheap electric power are essential and basic to industrial production. It could also be used to explain the development of economic activity in relatively large units of production, making much use of machinery and other capital assets (Ofor, 2017).

Since Nigeria became independent in 1960, achieving economic development through rapid industrialization has remained a major challenge. It is also not surprising that this has been the principal focus of the various administrations in the country (Iwuagwu, 2009).

This assertion is the same in most African countries. If the value chain is adequately managed, much value could be generated along the chain and that could go a long way in improving 
efficiency in the workplace. Value chain management may be used as a strategy not only to improve efficiency but also to strengthen organisational competitiveness. Several strategies have been used by many management strategists. For example, a manufacturer might require his parts suppliers to be located nearby to minimize the cost of transportation. By exploiting the upstream and downstream information flowing along the value chain, the firms may try to bypass the intermediaries creating new business models or in other ways, create improvements in their value system (Gurria, 2012).

Kherrazi, (2016) conducted a study on "Industrialization and Global Value Chains in Africa: challenges and strategies" which revealed that Africa's integration into the Global Value Chains is still limited to lower value-added activities but, at the same time, opportunities for upgrading to higher levels still exist. The study also concluded that African countries should open up to trade, prepare efficient logistics, promote the transfer of technology and build business ecosystems. In short, they should conduct a dual strategy in which they combine both integration and upgrading in GVCs to generate high values which is a prerequisite for their industrial development; just like the Chinese that have used this strategy to build and maintain their competitiveness in industrial development. (by developing their own high-tech products in the coastal/richer areas that create high value-added products and thus integrate into the Global Value Chain).

Advanced countries have understood the importance of managing an organization's value chain, hence they have tapped this strategy and have consistently maintained competitive advantages over their competitors especially from the LDCs. Competitive advantage cannot be understood by merely looking at an organization as a whole, it involves all activities performed by the organization which range from conception, through designing, producing, marketing, delivering and supporting its product. Each of these activities can contribute to the organisation's relative cost position and create a basis for differentiation (Ghemawat, 2002).

While the developed countries are breaking through with more market spaces (global value chain) like the virtual value chain, combining market spaces; the African countries are still trying to acclimatize with the traditional value chain i.e. physical value chain.

The introduction of global value chains (GVCs) in the late 1990s in the developed countries like China and America, provided a catalyst for accelerated change in the landscape of international investment and trade, with major, far-reaching consequences on governments as well as enterprises (Gurria, 2013).

It is through global Value chains that international businesses in developed countries were able to thrive and grow, this has also availed the governments of these nations opportunities to increase development revenues from Taxes i.e. Corporate Income Tax (CIT) (LeBlanc, Mathews and Mellbye, 2013).

Also in a study conducted by the International Crops Research Institute for the Semi-Arid Tropics (ICRISAT) which investigated the effect of strengthening the value chain for sweet

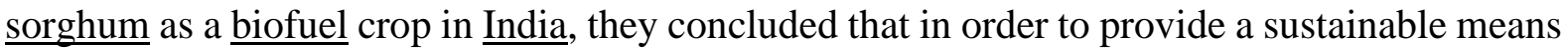
of making ethanol to increase the incomes of the rural poor, without sacrificing food and fodder security, while protecting the environment, the value chain for sweet sorghum should be strengthened (ICRISAT, 2013). 
African countries may consider strengthening the value chains of their primary products like the advanced countries. Malaysia, for example, depended on Nigeria for palm produce at some point, but they took the decision to grow and develop the oil palm plant which they got from Nigeria; today they not only export palm produce, they also use the raw material for their secondary products and the same Nigeria now buys some oil products from them.

Value chain analysis can be successfully used in large oil and petrochemical plant maintenance organizations to express how selection, planning, scheduling and execution of work can actually achieve leanness in the organisation especially in the area of maintenance where they are seen as part of the chain. If the value chain is adequately managed, much value could be generated along the chain and that could go a long way in improving efficiency in the workplace. By trying to minimize the underlying production costs along the value chain by any possible means, organisations may bypass unnecessary costs along the chain leaving the production process as efficient as possible. For instance, an organisation could decide to have their suppliers located closer to their organisation in order to reduce costs (http://www.technopedia.com/reg/real-world-data-fuels/).

Mitchell, Coles and Keane (2009) in their study discovered that Value chain analysis could be employed in the development sector as a means of identifying poverty reduction strategies by upgrading along the value chain. Microlinks (2009) in his study also confirmed that though Value chain in development sector had been commonly associated with export-oriented trade, evidence from his study brings to the limelight the importance of developing national and intra-regional chains in addition to international ones.

Value chain analysis could be used as a good strategy in any sector to enhance efficiency in every angle. The significance of value chain management cannot be over emphasized; an organisation's value chain embraces all activities involved in the entire production process of an organization, including the employment of resources, hence how these processes and resources are operated impacts significantly on organisational success. Organisational success determines survival and continuity, and this may result in industrialization.

\section{Methodology:}

The study is a qualitative study which evaluated scholarly works on Value chain management and through deductive reasoning came to its conclusions. Secondary sources of data were the major source of information for this paper hence the use of the internet proved very useful in this regard. The paper extensively used textbooks and journal articles.

\section{Conclusion:}

Through deductive reasoning, this paper came to the conclusion that the lack of competitiveness of African industries can be attributed to a lot of reasons but especially the inability of organizations to apply the full capabilities of their workforce and the inefficiency that arises from high costs in production and non-value adding activities in the value chain.

Businesses in Nigeria and other African nations seldom survive, not only because they are unable to produce enough secondary and tertiary products (which are the strength of industrial growth) but also because the activities lined up in the value chain of the few surviving industries are not properly managed and hence, they barely add value. This whole scenario weakens competitiveness in African industries and thus has kept their desire for industrialization an illusion. This paper reasons and re-emphasizes the fact that one of the ways to make African 
industrialization a reality is to manage the industrial value chain effectively. This way the up and coming industries in Nigeria and other African countries will be empowered to compete favourably and sustainably improve their respective positions in the global market place and hence capable of maintaining a global superior power.

This study hence recommends that in order to achieve this, governments and private business owners should help by investing in research and development to help shed more light on innovative ways to improve on value chain management. Private industries should also be supported financially so that they can elaborate their value chain system both locally and internationally; this will give them space and strength to develop superior performance globally.

\section{References}

Decision Support Tools: Porter's Value Chain. Cambridge University: Institute for Manufacturing (IfM) http://www.ifm.eng.cam.ac.uk/research/dstools/value-chain (retrieved on May 2018)

Ghemawat, Pankaj (2002) "Competition and Business Strategy in Historical Perspective" Business History Review, Harvard Business Review. SSRN 264528

Ofor, O (2017) Industrialization: Key to National Economic Independence

http://www.veritas.edu.ng/bulletin/prof-ofor-lecture-2017.php (retrieved on 12/05/18)

Iweriebor, E. (2017) Economic Recovery through Industrialisation, Diversification http://www.thisdaylive.com/index.php/economic-recovery-through-industrialisationdiversification/ (retrieved on May $3^{\text {rd }} 2018$ )

Iwuagwu, O (2009) "Nigeria and the Challenge of Industrial Development: the New Cluster Strategy" African Economic History Vol. 37 pp.151-180

Mitchell, J.; Coles, C. and Keane, J (2009) "Upgrading along Value chains: Strategies for Poverty Reduction in Latin America" Comercio y Pobreza en Latino America (COPLA). Briefing Paper. London: Overseas

Microlinks (2009) (Value Chain Development http://microlinks.kdid.org/vcwiki) Washington, D.C.: USAID.

Kherrazi, S. (2016) "Industrialization and Global Value Chains in Africa: challenges and strategies" étudiant du M2 IESC promotion 2015-2016 Master Intelligence Economique et Stratégies Compétitives. (www.Master- Intelligence- Economique- etStratégies- Compétitives)

Porter, M. E. (1985), Competitive Advantage: Creating and Sustaining Superior Performance. New York: Simon and Schuster.

Gurria, A (2013). Developing- a- sweet-sorghum ethanol- value- chain- archived- 2014-02-23 -at-the- wayback- machine. International Crops Research Institute for the Semi Arid 
Tropics ICRISAT, http://www.exploreit.icrisat.org/sites

LeBlanc, P; Matthews, S; Mellbye, K. (2013). The Tax Policy Landscape Five Years after the Crisis (Report). OECD Taxation Working Papers. France: OECD. Archived from the original on 18 March 2014. (http://www.keepeek.com/Digital-AssetManangement/oecd/taxation...)

Udeze, C. G (2013) Management of Development, Enugu: Rhyce Kereks Ltd

Value Chain Management; http://www.technopedia.com/reg/real-world-data-fuels/ (Retrieved on $2 / 05 / 18$ )

Weigert, M. (2016) "Regional before global: A value chain approach to industrialisation in West Africa" Analysis and news on African trade and Sustainable Development. 5(9) 15-26 